\title{
Correction to: Calling for an exponential escalation scheme in vaccine development for COVID-19
}

\author{
Martin Wehling ${ }^{1}$ iD
}

Published online: 24 August 2021

(c) The Author(s) 2021

\section{Correction to: European Journal of Clinical Pharmacology (2020) 76:1471-1472 https://doi.org/10.1007/s00228-020-02933-w}

The article Calling for an exponential escalation scheme in vaccine development for COVID-19, written by Martin Wehling, was originally published electronically on the publisher's internet portal on 16 June 2020 without open access. With the author(s)' decision to opt for Open Choice the copyright of the article changed on 14 May 2021 to $($ ) The Author(s) 2021 and the article is forthwith distributed under a Creative Commons Attribution 4.0 International License, which permits use, sharing, adaptation, distribution and reproduction in any medium or format, as long as you give appropriate credit to the original author(s) and the source, provide a link to the Creative Commons licence, and indicate if changes were made. The images or other third party material in this article are included in the article's Creative Commons licence, unless indicated otherwise in a credit line to the material. If material is not included in the article's Creative Commons licence and your intended use is not permitted by statutory regulation or exceeds the permitted use, you will need to obtain permission directly from the copyright holder. To view a copy of this licence, visit http://creativecommons.org/licenses/by/4.0.

The Original article has been corrected.

Open Access This article is licensed under a Creative Commons Attribution 4.0 International License, which permits use, sharing, adaptation, distribution and reproduction in any medium or format, as long as you give appropriate credit to the original author(s) and the source, provide a link to the Creative Commons licence, and indicate if changes were made. The images or other third party material in this article are included in the article's Creative Commons licence, unless indicated otherwise in a credit line to the material. If material is not included in the article's Creative Commons licence and your intended use is not permitted by statutory regulation or exceeds the permitted use, you will need to obtain permission directly from the copyright holder. To view a copy of this licence, visit http://creativecommons.org/ licenses/by/4.0/.
The original article can be found online at https://doi.org/10.1007/ s00228-020-02933-w.

\footnotetext{
Martin Wehling

martin.wehling@medma.uni-heidelberg.de

1 Institute of Clinical Pharmacology Mannheim,

Medical Faculty Mannheim, University of Heidelberg,

Theodor-Kutzer-Ufer 1-3, 68167 Mannheim, Germany
} 